\title{
COMBINED ANTERIOR PITUITARY AND NEUROHYPOPHYSEAL INSUFFICIENCY. STUDIES OF BODY FLUID SPACES AND RENAL FUNCTION *
}

\author{
BY M. MENCER MARTIN $\dagger$. \\ (From the Institute of Clinical Research, The Middlesex Hospital, London, England, and the \\ Department of Pediatrics, The Johns Hopkins University School of Medicine \\ and The Johns Hopkins Hospital, Baltimore, Md.)
}

(Submitted for publication March 10, 1958; accepted February 5, 1959)

Lesions of the neurohypophysis resulting in deficiency of antidiuretic hormone $(\mathrm{ADH})$ produce the clinical syndrome of diabetes insipidus, provided the anterior pituitary is functionally intact. If the anterior lobe is destroyed, manifestations of diabetes insipidus may not appear (1-3). The administration of cortisone or adrenocorticotropin $(\mathrm{ACTH})$ to patients with anterior pituitary insufficiency led to the recognition of coexisting neurohypophyseal failure (4-7). The presence of such combined defects is of physiological interest

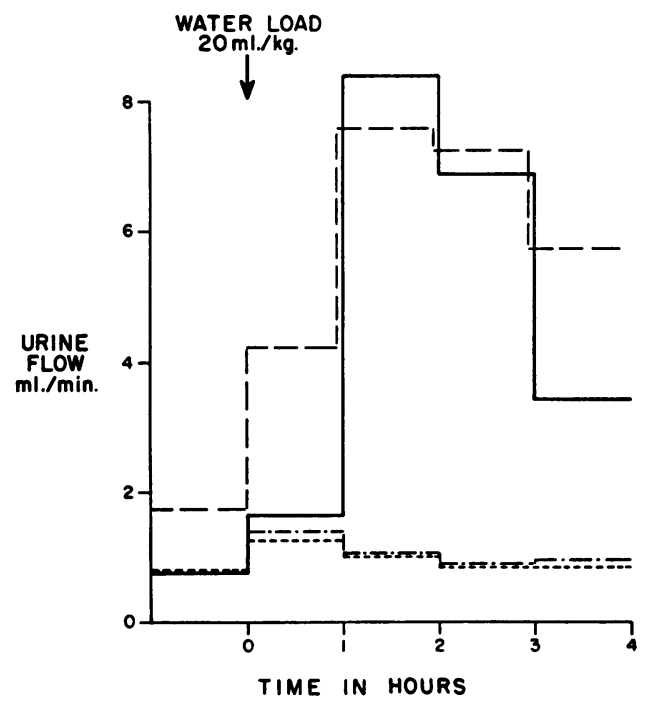

Fig. 1. Case 1: The Response to Acute Oral Water LOAding

--- , without treatment ; - - - - on triiodothyronine, $20 \mu \mathrm{g}$. three times a day; - after two days of cortisone, $50 \mathrm{mg}$. twice daily; and - - , after two days of corticotropin, $40 \mathrm{mg}$. twice daily.

* This work was carried out in part during the tenure of a Leverhulme Research Scholarship of the Middlesex Hospital Medical School, London, England.

+ Present address: Peter Bent Brigham Hospital, Boston, Mass. in that it approaches a condition in which the role of the kidney may be investigated in the human independent of hormonal control. The present study is an attempt at evaluating water metabolism and certain aspects of renal function in two patients with combined anterior pituitary and neurohypophyseal lesions.

\section{CASE REPORTS}

Case 1. A 25 year old white male was admitted to the Middlesex Hospital for investigation of hypogonadism. Physical examination was unremarkable except for a youthful facial appearance, eunuchoidal body proportions and absent secondary sexual characteristics. The visual fields were normal. $\mathrm{X}$-rays of the skull showed a beaten silver appearance with the pituitary fossa ballooned to $2 \mathrm{~cm}$. in diameter. $\mathrm{X}$-rays of the bones indicated a bone age of 14 years. Hemoglobin, total and differential white cell counts, blood urea, cholesterol, uric acid, alkaline phosphatase and serum electrolytes were within normal limits on repeated examination. Oral glucose tolerance and intravenous insulin sensitivity tests were also normal. An electrocardiogram showed low $\mathrm{T}$ waves and small QRS complexes in all leads compatible with a diagnosis of hypothyroidism. The BMR was -25 per cent (Robertson Reid Standard) but the thyroidal uptake of radioactive iodine was within the normal range. A standard water loading test $(20 \mathrm{ml}$. per $\mathrm{Kg}$. body weight) showed 19 per cent excretion in four hours (Figure 1). The Kepler-Robinson-Power index was 5.2. Urinary excretion of adrenal steroids was negligible but rose to high values after a standard ACTH test (8). While receiving $\mathrm{ACTH}$ the patient developed polydipsia and polyuria with a urine flow of over $5 \mathrm{~L}$. per day. These findings suggested ADH deficiency in addition to adenohypophyseal failure. An intravenous saline infusion test supported this assumption (Figure 2).

Case 2. A nine year old white male was seen in the Harriet Lane Home of the Johns Hopkins Hospital in 1950 because of the recent onset of defective vision. The following year headaches and occasional vomiting appeared. Examination revealed a left temporal field defect. X-rays of the skull demonstrated erosion of the sella turcica. 
(ofter oral cortisone
somg. b.d. for 2 days)
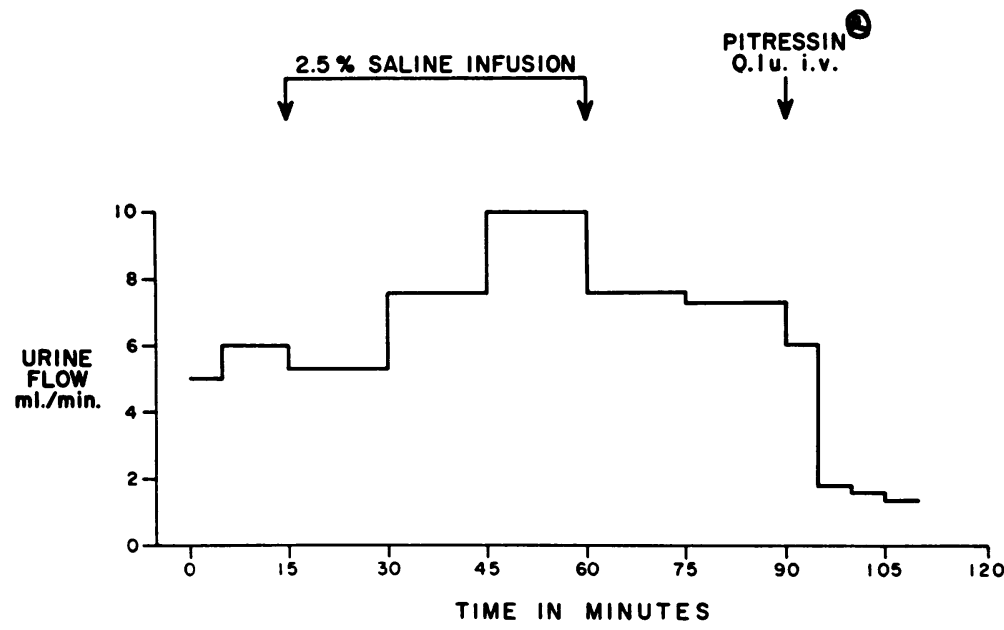

Fig. 2. Case 1: Intravenous Hypertonic Saline Test (0.25 ML. of 2.5 Per Cent Saline Per Kg. Per Minute for 45 Minutes)

There was no endogenous $\mathrm{ADH}$ release but following the injection of Pitressin $\$$, there was a fall in urine flow indicating normal responsiveness of the renal tubules.

In March, 1953, craniotomy was carried out with partial removal of a tumor which histologically proved to be an aberrant pinealoma. Following operation the patient received $5,000 \mathrm{r}$ to the pituitary region over a period of three weeks. Within three months diabetes insipidus developed and treatment was instituted. For the next four years he remained asymptomatic while receiving Pitres$\sin { }^{\circledR}$ (vasopressin), although growth lagged and puberty failed to occur. Follicle stimulating hormone remained absent from the urine and 17-ketosteroid excretion never exceeded $1.4 \mathrm{mg}$. per 24 hours. At the age of 14 years, substitution therapy with intramuscular depot testosterone was begun. Over the next 12 months physical and mental sluggishness became prominent and the protein-bound iodine fell to $1.9 \mu \mathrm{g}$. per $100 \mathrm{ml}$. Considerable improvement was noted following thyroid therapy.

Early in 1957 the boy noted that omission of Pitressin ${ }^{\circledR}$ caused no return of thirst or polyuria and so he stopped using it. The spontaneous disappearance of diabetes insipidus prompted re-evaluation at the age of 15.5 years. All therapy was discontinued four weeks prior to the present investigation.

Physical examination revealed slight stunting of growth, hypogonadism and sexual immaturity. There was a left temporal field defect, an unresponsive left pupil and left optic atrophy. Red and white blood counts and routine chemical determinations were normal except for a serum cholesterol of $334 \mathrm{mg}$. per $100 \mathrm{ml}$. and a protein-bound iodine of $1.9 \mu \mathrm{g}$. per $100 \mathrm{ml}$. Urinary 17-ketosteroids were $3.8 \mathrm{mg}$. per 24 hours and 17-hydroxycorticoids were absent from both urine and plasma. The water loading test showed a 9 per cent excretion in four hours. Following a test dose of cortisone poly- uria and polydipsia returned and an intravenous saline infusion test suggested absence of $\mathrm{ADH}$.

\section{PROCEDURE}

The subjects received a routine ward diet with fluids ad lib. Fluid intake was measured and urine output collected in 24 hour periods. Fasting daily weights were recorded at the beginning of each collection. All studies were performed following 14 hours of fasting and fluid deprivation. Information was obtained on renal function in Case 1 in the untreated state, following thyroid, and again after combined thyroid plus cortisone therapy and in Case 2 in the untreated state and on combined thyroid plus cortisone therapy at two dose levels.

Renal hemodynamics were assessed by measurements of renal plasma flow and glomerular filtration rate. After baseline values were obtained, the excretion of water and solute over a four hour observation period following oral water loading $(20 \mathrm{ml}$. per $\mathrm{Kg}$. body weight) were also measured. The following morning studies were made of water and solute excretion following oral urea loading (15 $\mathrm{Gm}$. urea in $50 \mathrm{ml}$. of water). In Case 1, total body water and extracellular fluid volume were measured simultaneously with the glomerular filtration rate and renal plasma flow.

Following control studies, Case 1 was given thyrotropic hormone, $10 \mathrm{mg}$. daily for two days, which increased radioactive iodine uptake by the thyroid gland from 40 to 54 per cent. Triiodothyronine, $20 \mu \mathrm{g}$. three times a day was then substituted and after three days of this treatment, studies were repeated. Triiodothyronine was continued, oral cortisone (12.5 mg. every eight hours) 
was added and after five days of this combined treatment, the studies, except for urea loading, were again repeated. In the course of the second study (on thyroid), and the third (on combined thyroid plus cortisone therapy), the acute effects of intravenous hydrocortisone-hemisuccinate (50 mg.) on fluid spaces and renal hemodynamics were also studied. Changes in inulin space were calculated by a method previously published (9). Prompt water diuresis was still impaired on combined thyroid plus cortisone therapy, with the last dose of cortisone given four hours before water loading. Observations on water and solute excretion, though not of renal hemodynamics, were therefore repeated after the dose of cortisone was increased to $100 \mathrm{mg}$. four hours before water or urea administration.

In Case 2, following control observations, substitution therapy consisting of desiccated thyroid, $120 \mathrm{mg}$. daily, and intramuscular cortisone, $5 \mathrm{mg}$. twice daily, was given. On the seventh day of therapy, the studies, except for urea loading, were repeated. The cortisone dosage was then doubled and the same studies were again made on the seventh day of this regimen.

Control subjects. Studies of the responses to oral water and urea loading, carried out under the same conditions of fasting and fluid deprivation outlined above, were obtained in a patient with untreated diabetes insipidus, a patient with uncomplicated and untreated anterior pituitary insufficiency, and a normal subject. Studies were not repeated following hormone administration nor were renal hemodynamics investigated.

Total body water was measured by the volume of distribution of antipyrine (10) and extracellular fluid volume by the distribution of inulin (11). Inulin was determined by the resorcinol-thiourea method (12). Glomerular filtration rate was taken as the clearance of inulin, and renal plasma flow as the clearance of paraaminohippuric acid (13). The factor 0.9 was used for correction for plasma water. No correction was made for renal dead space in calculating extracellular water. Urine and plasma osmolalities were determined by freezing point depression using a modified Beckman thermom- eter in Case 1 and a Fiske Associates Osmometer in Case 2. Osmolal and free water clearances were calculated using the formulae of Wesson and Anslow (14). Sodium and potassium were determined by flame photometry and chloride by the potentiometric method of Sanderson (15). Urea was estimated by a modification of the method of Barrett (16).

\section{RESULTS}

\section{Case 1}

Body fluid compartments (Table I). The relationship of total body water and extracellular fluid volume to body weight was within normal limits in the untreated patient. Thyroid decreased body weight, total body water and extracellular fluid volume. The addition of cortisone further reduced body weight and total body water but caused no alteration in extracellular fluid volume either during prolonged oral or intravenous administration.

Clearance studies (Table I). In the untreated patient, glomerular filtration was markedly reduced. Renal plasma flow was not measured. Thyroid raised the glomerular filtration rate; however, it was not returned to normal. The addition of cortisone returned the glomerular filtration rate and renal plasma flow to normal.

In the acute experiments, intravenous hydrocortisone increased the glomerular filtration rate when superimposed both on thyroid and on combined thyroid plus cortisone therapy. The effect on renal plasma flow was less consistent. With steroid infusion superimposed on thyroid, renal plasma flow increased appreciably. On thyroid plus cortisone administration, renal plasma flow

TABLE I

The effect of hormone administration on the body fluid compartments, renal plasma flow, glomerular filtration rate and electrolyte excretion of Case 1

\begin{tabular}{|c|c|c|c|c|c|c|c|c|c|c|}
\hline & Date & $\begin{array}{l}\text { Body } \\
\text { wgt. }\end{array}$ & $\begin{array}{l}\underset{\mathrm{TBW}}{\left(\mathrm{V}_{\mathbf{A}}\right)} \\
\text { (1) }\end{array}$ & $\underset{\left(V_{I N}\right)}{\text { ECF }}$ & $\begin{array}{c}\mathrm{RPF}^{\mathrm{R}} \\
\left(\mathrm{CPAH}_{\mathrm{PAH}}\right)\end{array}$ & $\begin{array}{l}\text { GFR* } \\
\text { (CIN) }\end{array}$ & $\underset{\mathrm{Na}}{\mathrm{Plasma}}$ & $\mathrm{C}_{\mathrm{N}}$ & $\underset{\mathbf{K}}{\text { Plasma }}$ & $\mathbf{C r}_{\mathbf{r}}$ \\
\hline I. Control period & $6 / 14 / 56$ & $\begin{array}{c}K g . \\
64.8\end{array}$ & $\begin{array}{c}L . \\
29.0\end{array}$ & $\begin{array}{c}L . \\
11.2\end{array}$ & ml./min. & $\begin{array}{c}\text { ml./min. } \\
69\end{array}$ & $\begin{array}{c}m E q . / L . \\
140\end{array}$ & $\begin{array}{c}m l . / m i n \\
0.460\end{array}$ & $\begin{array}{c}m E q . / L \\
3.6\end{array}$ & $\begin{array}{c}\operatorname{ml} . / \min \\
4.78\end{array}$ \\
\hline \multirow{2}{*}{$\begin{array}{l}\text { II. On triiodothyronine, } \\
20 \mu \mathrm{g} \text {. t.i.d. } \\
60 \text { min. after I.V. } \\
\text { hydrocortisone }\end{array}$} & \multirow[t]{2}{*}{$6 / 22 / 56$} & \multirow[t]{2}{*}{63.2} & \multirow[t]{2}{*}{27.8} & 10.3 & 470 & 96 & 147 & 0.659 & 3.8 & 4.61 \\
\hline & & & & 10.5 & 610 & 111 & 145 & 0.643 & 3.7 & 5.07 \\
\hline \multirow{2}{*}{$\begin{array}{l}\text { III. On triiodothyronine } \\
\text { and } 37.5 \mathrm{mg} \text {. cortisone } \\
60 \text { min. after I.V. } \\
\text { hydrocortisone }\end{array}$} & \multirow[t]{2}{*}{$6 / 28 / 56$} & \multirow[t]{2}{*}{61.9} & \multirow[t]{2}{*}{26.4} & 10.8 & 527 & 116 & 141 & 1.23 & 3.6 & 6.48 \\
\hline & & & & 10.9 & 545 & 126 & 140 & 1.35 & 3.7 & 7.25 \\
\hline
\end{tabular}

* Mean of three collection periods, corrected to standard surface area of 1.73 M.2. 
TABLE II

The effect of therapy on renal hemodynamics, urine volumes, urine osmolalities and solute output in the two subjects with anterior and posterior pituitary insufficiency

\begin{tabular}{|c|c|c|c|c|c|c|c|}
\hline & Medication & RPF* & GFR* & FF & $\begin{array}{c}\text { Mean urine } \\
\text { volume }\end{array}$ & $\begin{array}{c}\text { Mean } \\
\text { osmolality }\end{array}$ & $\begin{array}{c}\text { Mean } \\
\text { total } \\
\text { solute } \\
\text { excretion }\end{array}$ \\
\hline & & $\operatorname{ml} . / \min$ & ml./min. & & ml. $/ 24$ hrs. & mOsm./L. & $\underset{\text { hrs. }}{m \text { mosm. }} / 24$ \\
\hline \multirow[t]{4}{*}{ Case I } & & & 69 & & \multirow{3}{*}{$\begin{array}{c}2,260 \\
(2,100-2,400) \\
2,270 \\
(2,200-2,500) \\
4,619 \dagger\end{array}$} & \multirow{3}{*}{$\begin{array}{c}470 \\
(600-440) \\
425 \\
(480-360) \\
278 \dagger\end{array}$} & 1,060 \\
\hline & \multirow{3}{*}{$\begin{array}{l}\text { Triiodothyronine, } \\
20 \mu \text { g. t.i.d. } \\
\text { Triiodothyronine, } \\
20 \mu \text { g. t.i.d. } \\
\text { Cortisone, } \\
37.5 \mathrm{mg} \text {. daily }\end{array}$} & 470 & 96 & 0.202 & & & 970 \\
\hline & & 527 & 116 & 0.220 & & & $1,250 \dagger$ \\
\hline & & & & & S.E. \pm 456 & S.E. \pm 21 & \\
\hline \multirow[t]{3}{*}{ Case II } & None & 460 & 103 & 0.224 & \multirow{2}{*}{$\begin{array}{c}3,300 \\
\text { S.E. } \pm 111 \\
4,760 \\
\text { S.E. } \pm 156\end{array}$} & \multirow{2}{*}{$\begin{array}{c}320 \\
\text { S.E. } \pm 31 \\
225 \\
\text { S.E. } \pm 19\end{array}$} & 1,080 \\
\hline & $\begin{array}{l}\text { Thyroid, } 120 \text { mg. q.d. } \\
\text { I.M. cortisone, } \\
5 \text { mg. b.i.d. }\end{array}$ & 620 & 121 & 0.196 & & & 1,057 \\
\hline & $\begin{array}{l}\text { Thyroid, } 120 \text { mg. q.d. } \\
\text { I.M. cortisone, } \\
10 \text { mg. b.i.d. }\end{array}$ & 650 & 141 & 0.216 & $\begin{array}{c}5,000 \\
\text { S.E. } \pm 224\end{array}$ & $\begin{array}{c}255 \\
\text { S.E. } \pm 12\end{array}$ & 1,270 \\
\hline
\end{tabular}

* Mean of three collection periods corrected to standard surface area of 1.73 M.2.

$\dagger$ Excludes days when $100 \mathrm{mg}$. cortisone was given.

was higher than on thyroid alone and the response to intravenous hydrocortisone was within limits of experimental error. Intravenous hydrocortisone produced no appreciable change in sodium excretion, but enhanced potassium excretion when superimposed both on thyroid and combined thyroid plus cortisone therapy.

Twenty-four hour urine and solute excretion (Table II, Figure 3). The control 24 hour urine specimens were distinctly hypertonic. Thyroid administration reduced urine osmolality but had little effect on urine volumes. Total daily solute excretion was less. The addition of cortisone induced polyuria with the production of an approximately isotonic urine, except when the larger dosage of cortisone $(100 \mathrm{mg}$.) was given. With this larger dosage, urine volumes exceeded $6 \mathrm{~L}$. and urine osmolalities fell below 200 mOsm. per $\mathrm{Kg}$. Cortisone increased total daily solute excretion.

Response to water and urea loading (Figure 4). The untreated patient was unable to excrete a water load promptly. Urine flow remained below $2 \mathrm{ml}$. per minute and fell progressively, as did solute excretion. Urine osmolalities remained virtually unchanged at approximately $600 \mathrm{mOsm}$. per Kg., although plasma osmolalities dropped from 315 to $290 \mathrm{mOsm}$. per $\mathrm{Kg}$. Urea loading produced an increased urine flow. Urine osmo- lality dropped to $510 \mathrm{mOsm}$. per $\mathrm{Kg}$. in the third hour but rose again thereafter. Approximately 20 per cent of the urea ingested was excreted over the four hour period. Thyroid appeared to have no significant effect on water or urea load excre-

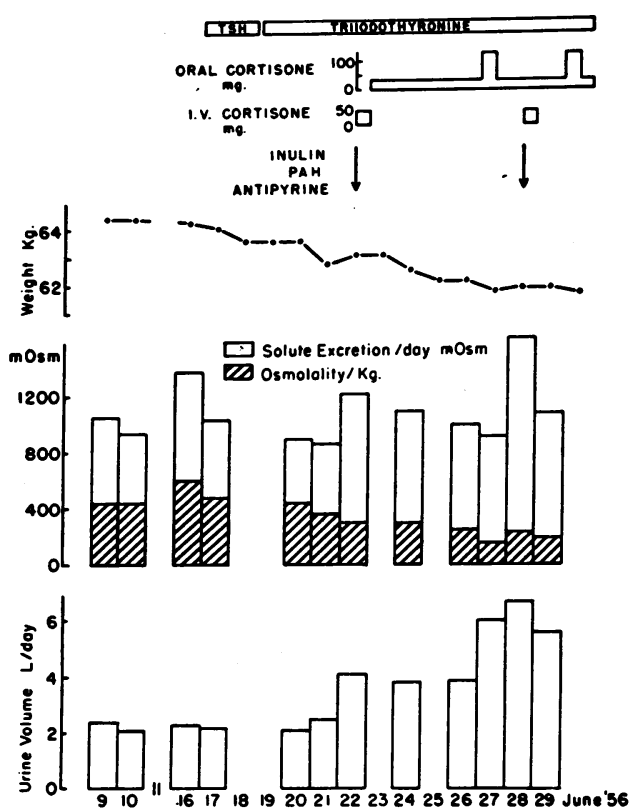

Fig. 3. Case 1: The Effect of Hormone Therapy on Body Weight, 24 Hour Urine Volumes, Urine Osmolalities and Total Solute Excretion 
ANTERIOR AND POSTERIOR HYPOPHYSEAL FAILURE
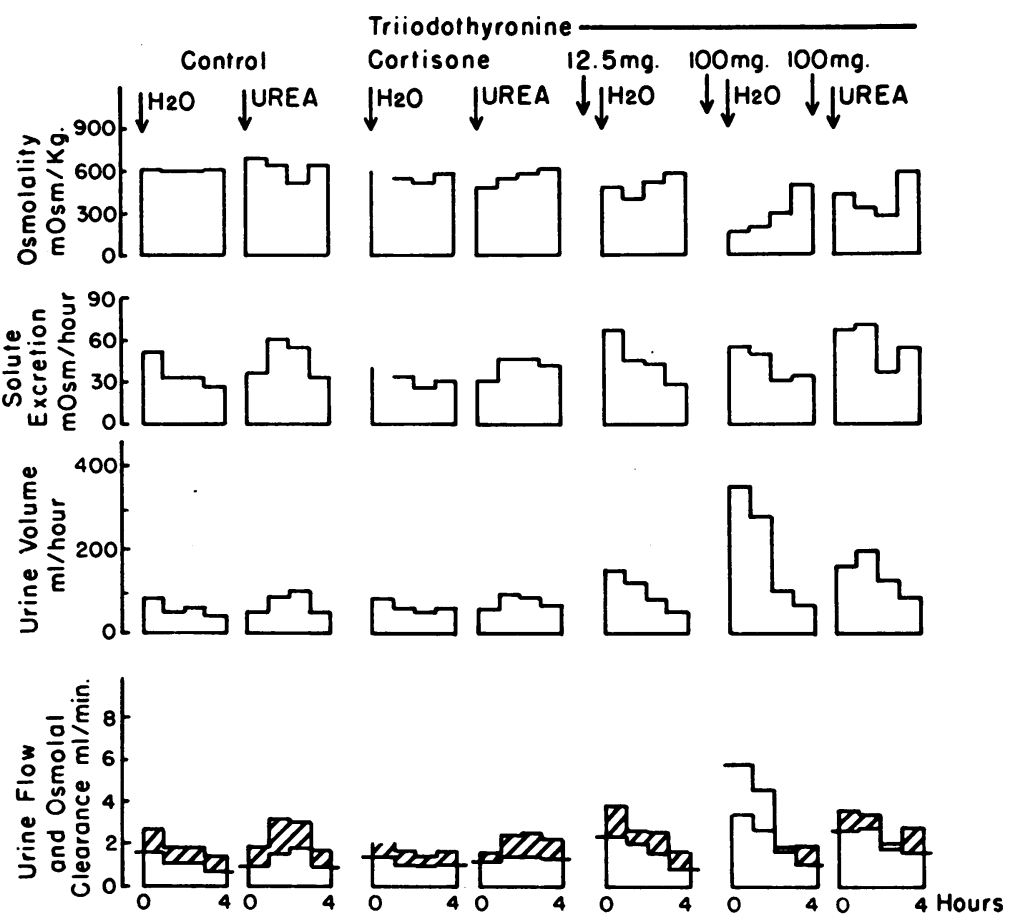

Fig. 4. Case 1: The Responses to Oral Water and Urea Loading

Urine volumes, osmolalities and solute excretion are shown for each of the four hourly observation periods. The bottom row shows urine flow and osmolal clearance. Where osmolal clearance exceeds urine flow the shaded area indicates the amount of solute-free water abstracted in the concentrating operation. Where urine flow exceeds osmolal clearance, the clear area above the blocks indicates free water clearance.

tion. When $12.5 \mathrm{mg}$. oral cortisone was given four hours before water ingestion, urine flow rose to $2.42 \mathrm{ml}$. per minute and solute excretion to 1.12 mOsm. per minute, respectively. Urine osmolalities, although somewhat lower, never fell below $382 \mathrm{mOsm}$. per $\mathrm{Kg}$. When $100 \mathrm{mg}$. cortisone was given four hours before the test, urine osmolalities dropped to $159 \mathrm{mOsm}$. per $\mathrm{Kg}$. and urine flow rose to $5.75 \mathrm{ml}$. per minute. Free water clearance was established. Cortisone had no effect on solute excretion following urea. Approximately 20 per cent of the urea ingested was excreted over four hours, as in the control study.

\section{Case 2}

The findings were similar to those in Case 1, except for quantitative differences. Clearance studies, 24 hour urine volumes and solute excretion are summarized in Table II. Although total daily solute excretion was of similar magnitude in the two patients, the 24 hour urine volumes in Case 2 were greater and urine osmolalities lower. The control glomerular filtration rate was considerably higher and approached normal. On combined thyroid plus cortisone therapy, the glomerular filtration rate and renal plasma flow rose to normal. There was again a significant increase in urine volume and a fall in urine osmolality, with the production of a hypotonic urine and overt diabetes insipidus. Total daily solute excretion rose as in Case 1 when the dose of cortisone was increased.

Control responses to water and urea loading were similar to those of Case 1. Urine osmolalities remained at approximately $500 \mathrm{mOsm}$. per $\mathrm{Kg}$. Urine flow and solute excretion varied in the same direction. The response to water loading on thyroid plus cortisone is shown in Figure 5. 
There was no difference in response using the larger dose of cortisone. In both instances free water clearance was established although only half the water taken was eliminated. Plasma osmolalities at the time the water load was given were $320 \mathrm{mOsm}$. and $330 \mathrm{mOsm}$. per $\mathrm{Kg}$. and fell to 290 and 304 mOsm. per Kg., respectively.

\section{Analysis ${ }^{1}$}

The observations, with the exception of those made under cortisone therapy, were subjected to a covariance analysis. The regression of urine flow on solute excretion did not change significantly between patients, or with thyroid therapy $(p>0.20)$. For all the values, the regression line, shown in Figure 6 , was highly significant $(p<0.002)$. The urine flow values observed under different conditions, when adjusted for differences in solute excretion, were not significantly different from each other $(p>0.10)$.

The regression equation is:

$$
\mathrm{Y}=0.148+1.484 \mathrm{X}
$$
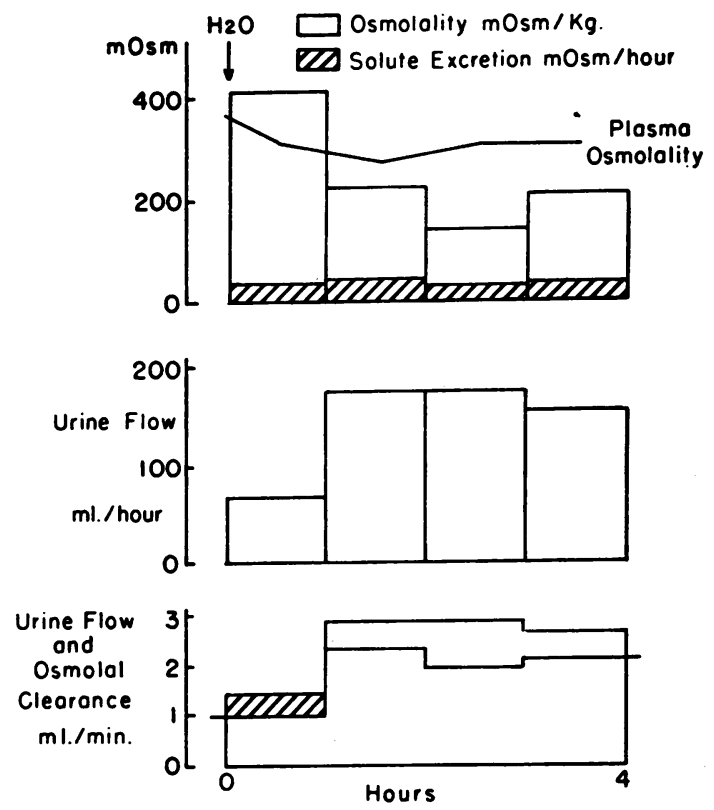

Fig. 5. Case 2: The Response to Water Loading on Thyroid and Intramuscular Cortisone, 5 Mg. Twice DAIIY

The mode of presentation is as in Figure 4.

1 The statistical analysis was made by Dr. Mindel C. Sheps, Department of Preventive Medicine, Harvard Medical School.

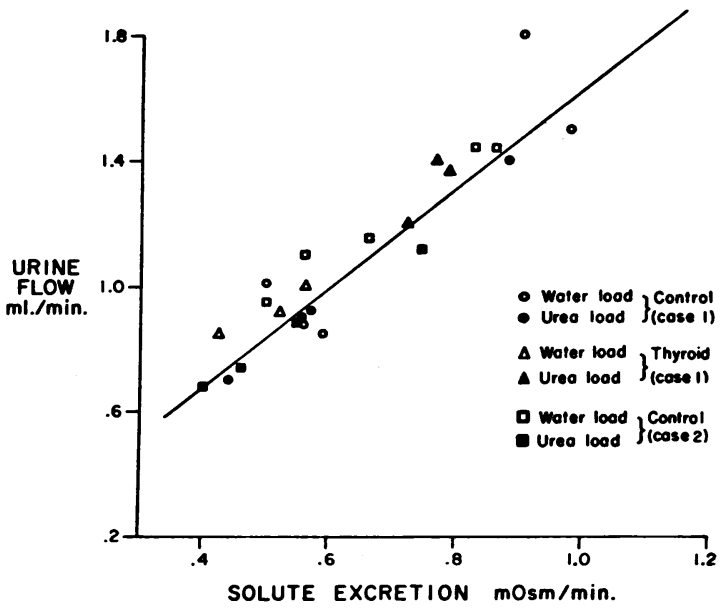

Fig. 6. The Relationship between Solute Excretion and Urine Flow in the Absence of Cortisone Administration in the Two Patients with ComBINED ANTERIor Piturtary aNd NeUrohypophyseal. FAILURE

The correlation is highly significant $(\mathrm{p}<0.002)$.

where $\mathrm{Y}=$ urine flow in $\mathrm{ml}$. per minute,

$\mathrm{X}=$ solute excretion in mOsm. per minute.

\section{Controls}

The responses to water and urea loading are summarized in Figures 7 and 8. In anterior hypopituitarism the same failure of prompt water diuresis was noted as was present in the patients with combined anterior pituitary and neurohypophyseal deficiency. Urine flow never exceeded $1.33 \mathrm{ml}$. per minute and urine osmolalities remained approximately $600 \mathrm{mOsm}$. per $\mathrm{Kg}$. Urine flow was a function of solute excretion. Only 22 per cent of the water ingested was excreted in four hours, confirming the findings of Burston and Garrod (17). Urea caused maximal concentration of the urine with osmolalities approaching the normal upper limit of $1,400 \mathrm{mOsm}$. per $\mathrm{Kg}$.

The patient with uncomplicated diabetes insipidus excreted a water load promptly. Urine flow was high and urine osmolalities were about 100 mOsm. per $\mathrm{Kg}$. When given urea after 14 hours dehydration, urine osmolalities rose to $420 \mathrm{mOsm}$. per $\mathrm{Kg}$., indicating that a hypertonic urine can be elaborated in the absence of ADH.

The normal subject showed a wide range of renal concentrating and diluting capacity. Following water ingestion, maximal urine flow of 

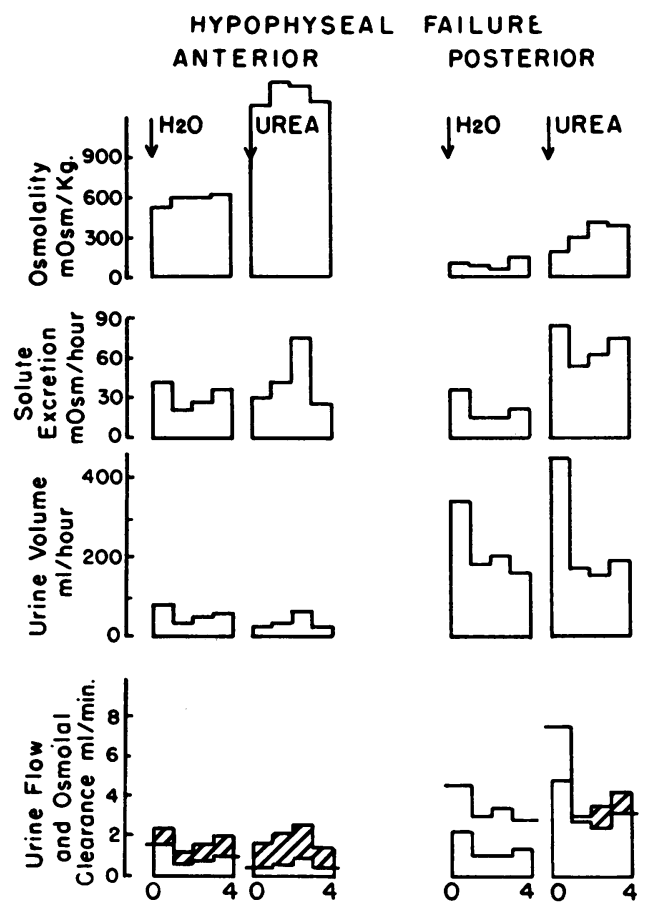
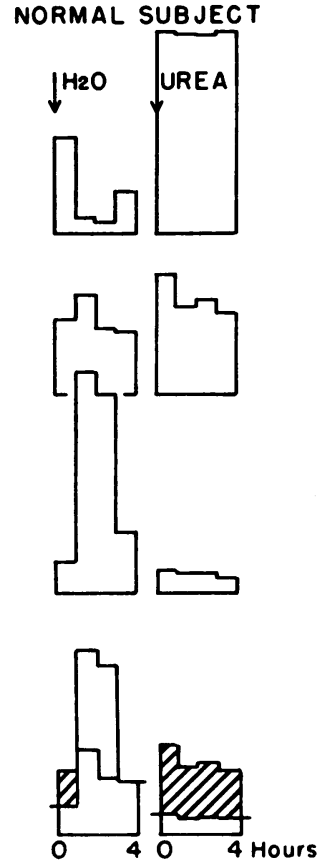

Fig. 7. The Response to Oral Water and Urea Loading of the Control Subjects-The Patient with Anterior Hypopituitarism, the Patient with Posterior Hypopituitarism and the Normal Man

The mode of presentation is as in Figure 4.

$9.3 \mathrm{ml}$. per minute was reached during the second hour. As urine flow increased, urine osmolality fell despite a rise in solute excretion. Following urea there was little change in urine flow and urine osmolality remained at the normal upper limit of $1,400 \mathrm{mOsm}$. per $\mathrm{Kg}$.

\section{DISCUSSION}

A few patients with anterior pituitary and neurohypophyseal insufficiency have been reported in the literature (4-7), but only one case has been studied in detail. This patient, described by Leaf, Mamby, Rasmussen and Marasco (5), usually excreted a hypotonic urine even after prolonged fluid deprivation. She was capable of prompt water diuresis and showed no response to cortisone or ACTH. The authors concluded that the subject probably had enough anterior pituitary and adrenocortical function left to maintain the renal concentrating defect of neurohypophyseal failure, which was further complicated by a lesion of the thirst center.

In the two subjects of the present study the diag- nosis of combined anterior pituitary and neurohypophyseal failure was based of necessity upon clinical evaluation. The most striking finding was the excretion of a hypertonic urine of relatively fixed osmolality and inability to excrete a water load promptly despite marked changes in plasma osmolality. That the high urine concentration was caused by minimal secretion of ADH seems unlikely in view of the absence of any appreciable change following water as well as urea loading. Furthermore, the close correlation between urine flow and solute output would not have been present if the proportion of water reabsorbed from the glomerular filtrate had varied more than slightly. The increased urine volumes in Case 2 may suggest residual anterior pituitary function. Although this cannot be excluded, it was obviously inadequate to maintain the concentrating defect characteristic of uncomplicated neurohypophyseal insufficiency. Cortisone both corrected the incapacity for prompt water diuresis and "unmasked" the latent diabetes insipidus.

Changes in the glomerular filtration rate were 
reflected in the urine concentration. In the absence of hormone administration, urine osmolality was high and glomerular filtration low, in accordance with other published data $(4,7,17)$. Thyroid raised the glomerular filtration rate with a concomitant fall in urine concentration. When cortisone was added to the treatment in Case 1, renal plasma flow and glomerular filtration rate approached normal levels and urine isosmolal concentrations (Table II). It seems reasonable, therefore, to attribute the hypertonicity of the urine, at least in part, to the reduction in glomerular filtration rate with a diminution in the volume filtered in all nephrons rather than to a selective cessation of filtration in a group of nephrons. This interpretation is in accord with recent experimental evidence on the production of hypertonic urine by lowering the glomerular filtration rate in the absence of $\operatorname{ADH}(18,19)$.

Prompt water diuresis with the establishment of free water clearance was still impaired in Case 1 (Figure 4, Experiment 5), despite a normal renal plasma flow of $527 \mathrm{ml}$. per minute and a glomerular filtration rate of $116 \mathrm{ml}$. per minute when the patient was on triiodothyronine, $20 \mu \mathrm{g}$. three times a day, and cortisone, $37.5 \mathrm{mg}$. daily (Table I). Only after $100 \mathrm{mg}$. cortisone was given preceding the test was free water clearance present, presumably because the smaller dose of cortisone had lost its effectiveness by the end of four hours when the water was ingested (20).

In Case 2, free water clearance was present on thyroid and cortisone therapy at both dose levels. The excretion of only 50 per cent of the water load is believed to have been due to dehydration, as the experiments were carried out during a heat wave. With adequate water ingestion, this patient achieved a urine flow in excess of $10 \mathrm{ml}$. per minute, preceding the saline test.

The effect of cortisone in restoring the capacity for free water clearance cannot be ascribed to increased breakdown of protein and provision of urinary solute as urea, since urea administration had no such effect. It seems well documented $(18,19)$ that a lowered glomerular filtration rate is associated with impaired water diuresis, but restoration of the glomerular filtration rate in Case 1 to normal did not appear to correct the defect in accord with other data $(21,22)$. It is sug- gested, therefore, that cortisone, in addition to restoring the glomerular filtration rate toward normal levels, may bring about an intrinsic change in the renal tubular handling of water, possibly as a reflection of a generalized cellular effect. That steroids can affect the renal tubular reabsorption of water has been shown (23). The hypothesis is advanced that the presence of adrenocortical hormone is required in addition to a normal glomerular filtration rate for the production of free water clearance. Whether steroids effect a re-

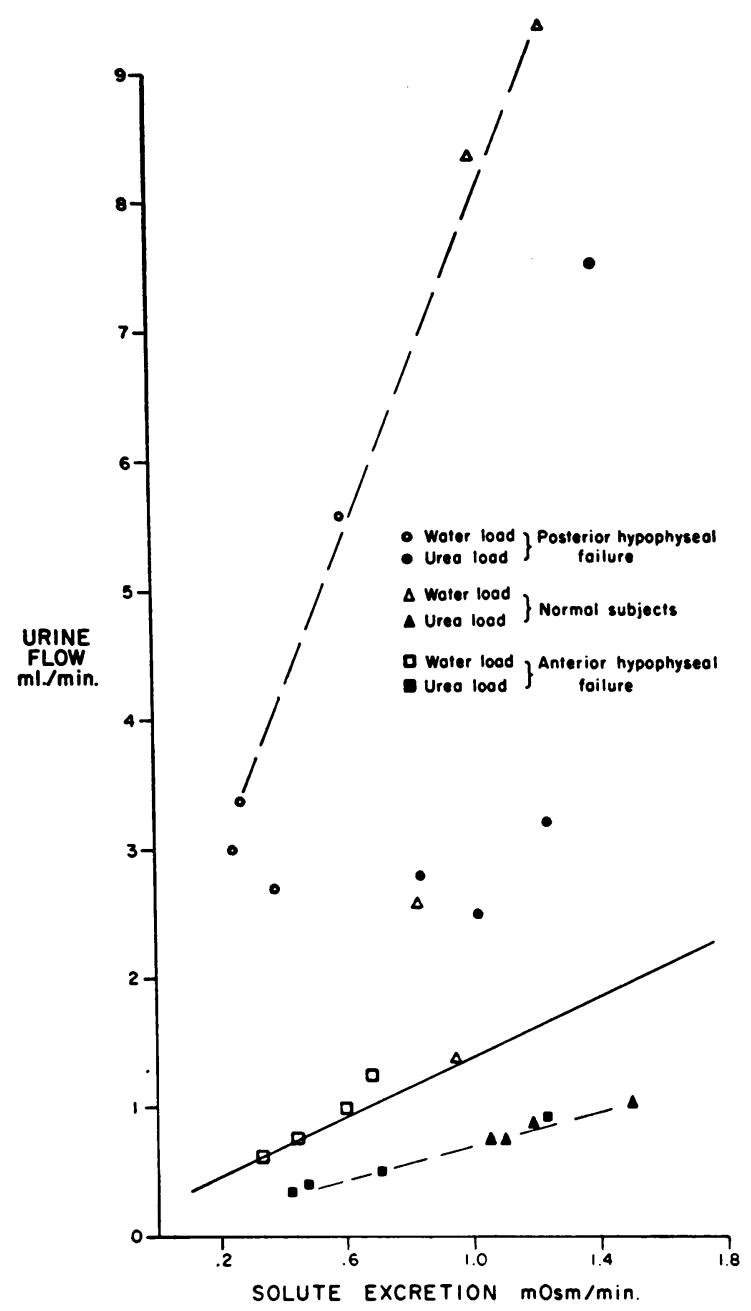

Fig. 8. The Relationship of Urine Flow to Solute Excretion in the Control Subjects-The Patient with Diabetes Insipidus, the Patient with Anterior Pituitary Insufficiency and the Normal Man

The continuous line corresponds to the regression line in Figure 6. The broken lines indicate the extreme ranges of concentration and dilution met within the present investigation. 
distribution of solute absorption between the proximal and distal tubule or an alteration in the permeability of the renal tubular epithelium to water cannot be deduced from the present findings and further studies in pituitary and adrenocortical insufficiency are needed.

The normal subject illustrated the full range of physiological adaptation to water and solute loading. ${ }^{2}$ Only one extreme of this range was attained by the patient with anterior hypopituitarism, who was able to elaborate a highly concentrated urine, but not a dilute urine. Only the other extreme was reached by the patient with diabetes insipidus who alternately was able to elaborate a hypotonic urine but had lost normal concentrating capacity. The production of a hypertonic urine in this patient in response to dehydration and urea loading was most likely the result of a reduction in the glomerular filtration rate. The patients with both anterior pituitary and neurohypophyseal insufficiency had lost the capacity for maximal concentration and dilution and were able to alter renal excretory function only within the narrow range imposed by the limited variability of the glomerular filtration rate. That the lack of prompt water diuresis in anterior hypopituitarism is the result of a relative or absolute $\mathrm{ADH}$ excess $(24,25)$ seems most unlikely in view of the persistence of the defect in the present cases with absent neurohypophyseal function and similar cases reported by others $(4,6,7)$. A comparison of the findings in the various cases clearly indicates the range of activity and the absence of any interrelationship of $\mathrm{ADH}$ and adrenocortical hormones. Adrenocortical steroids restored the ability for free water clearance independent of the functional integrity of the neurohypophyseal antidiuretic mechanism. That the normal action and release of $\mathrm{ADH}$ is not interfered with by adrenocortical steroids has previously been demonstrated (26).

\section{SUM MARY AND CONCLUSIONS}

Studies are reported in two patients with space occupying lesions in the region of the sella turcica in whom a combined deficiency of anterior pitui-

2 The high urine osmolality obtained with urea was due to the absence of osmotic diuresis. Urea is a poor diuretic solute because of its large volume of distribution and moderate tubular reabsorption. tary and neurohypophyseal function seems reasonably certain. Renal plasma flow, glomerular filtration rate and the responses to water and urea loading have been examined before and after hormone administration. In one patient total body water and extracellular fluid volume were also measured.

In the absence of cortisone the urine was hypertonic at all times and urine flow was a function of solute excretion. Cortisone raised the glomerular filtration rate to normal and restored the capacity for free water clearance. It is suggested that cortisone, in addition to raising the glomerular filtration rate, may also affect renal tubular water transport because prompt water diuresis was still impaired in one case on inadequate cortisone replacement despite a normal renal plasma flow and glomerular filtration rate.

A comparison of the data obtained in patients with combined defects and those in patients with diabetes insipidus and anterior hypopituitarism suggests that antidiuretic hormone (ADH) and cortisone exert their effects independently.

\section{REFERENCES}

1. Von Hann, F. Über die Bedeutung der Hypophysenveränderungen bei Diabetes Insipidus. Frankfurt. Z. Path. 1918, 21, 337.

2. Richter, C. P. Experimental diabetes insipidus; its relation to the anterior and posterior lobes of the hypophysis. Amer. J. Physiol. 1934-35, 110, 439.

3. White, H. L., and.Heinbecker, P. Pituitary regulation of water exchange in the dog and monkey. Amer. J. Physiol. 1937, 118, 276.

4. Garrod, O., and Burston, R. A. The diuretic response to ingested water in Addison's disease and panhypopituitarism and the effect of cortisone thereon. Clin. Sci. 1952, 11, 113.

5. Leaf, A., Mamby, A. R., Rasmussen, H., and Marasco, J. P. Some hormonal aspects of water excretion in man. J. clin. Invest. 1952, 31, 914.

6. Engstrom, W. W., and Liebman, A. Chronic hyperosmolarity of the body fluids with cerebral lesion causing diabetes insipidus and anterior pituitary insufficiency. Amer. J. Med. 1953, 15, 180.

7. Stribling, S. H., and Spurr, C. L. Polydipsia as a mechanism for the production of cortisone "diuresis." Clin. Res. Proc. 1955, 3, 14.

8. Martin, M. M., Gray, C. H., Livingstone, J. L., and Lunnon, B. J. Urinary metabolites of cortisol in adrenal insufficiency and in pituitary eunuchoidism. J. clin. Endocr. 1957, 17, 1168. 
9. Hills, A. G., Chalmers, T. M., Webster, G. D., Jr., and Rosenthal, $O$. Adrenal cortical regulation of the distribution of water and electrolytes in the human body. J. clin. Invest. 1953, 32, 1236.

10. Soberman, R., Brodie, B. B., Levy, B. B., Axelrod, J., Hollander, V., and Steele, J. M. The use of antipyrene in the measurement of total body water in man. J. biol. Chem. 1949, 179, 31.

11. Schwartz, I. L., Schachter, D., and Freinkel, N. The measurement of extracellular fluid in man by means of a constant infusion technique. J. clin. Invest. 1949, 28, 1117.

12. Roe, J. H., Epstein, J. H., and Goldstein, N. P. Photometric method for the determination of inulin in plasma and urine. J. biol. Chem. 1949, 178, 839.

13. Smith, H. W., Finkelstein, N., Aliminosa, L., Crawford, B., and Graber, M. The renal clearances of substituted hippuric acid derivatives and other aromatic acids in dog and man. J. clin. Invest. 1945, 24, 388.

14. Wesson, L. G., Jr., and Anslow, W. P., Jr. Effect of osmotic and mercurial diuresis on simultaneous water diuresis. Amer. J. Physiol. 1952, 170, 255.

15. Sanderson, P. H. Potentiometric determination of chloride in biological fluids. Biochem. J. 1952, $52,502$.

16. Barrett, J. F. A modified Nessler's reagent for the micro-determination of urea in tungstic acid blood filtrate. Biochem. J. 1935, 29, 2442.

17. Burston, R. A., and Garrod, O. The variability of the lowered glomerular filtration rate in Addison's disease and panhypopituitarism and the effect of cortisone thereon. Clin. Sci. 1952, 11, 129.

18. Berliner, R. W., and Davidson, D. G. Production of hypertonic urine in the absence of pituitary antidiuretic hormone. J. clin. Invest. 1957, 36, 1416.
19. del Greco, F., and de Wardener, H. E. The effect on urine osmolarity of a transient reduction in glomerular filtration rate and solute output during "water" diuresis. J. Physiol. (Lond.) 1956, 131, 307.

20. Nelson, D. H., Sandberg, A. A., Palmer, J. G., and Tyler, F. H. Blood-levels of 17-hydroxycorticosteroids following the administration of adrenal steroids and their relation to levels of circulating leukocytes. J. clin. Invest. 1952, 31, 843.

21. Garrod, O., Davies, S. A., and Cahill, G., Jr. The action of cortisone and desoxycorticosterone acetate on glomerular filtration rate and sodium and water exchange in the adrenalectomized dog. $\mathrm{J}$. clin. Invest. 1955, 34, 761.

22. Kleeman, C. R., Maxwell, M. H., and Rockney, R. E. Mechanisms of impaired water excretion in adrenal and pituitary insufficiency. I. The role of altered glomerular filtration rate and solute excretion. $\mathrm{J}$. clin. Invest. 1958, 37, 1799.

23. Raisz, L. G., McNeely, W. F., Saxon, L., and Rosenbaum, J. D. The effects of cortisone and hydrocortisone on water diuresis and renal function in man. J. clin. Invest. 1957, 36, 767.

24. Slessor, A. Studies concerning the mechanism of water retention in Addison's disease and hypopituitarism. J. clin. Endocr. 1951, 11, 700.

25. Gaunt, R., Birnie, J. H., and Eversole, W. J. Adrenal cortex and water metabolism. Physiol. Rev. 1949, 29, 281.

26. Luft, R., Olivecrona, H., Sjögren, B., Ikkos, D., and Ljunggren, $H$. Therapeutic results of hypophysectomy in metastatic carcinoma of the breast and in severe diabetes mellitus; adrenocortical function after hypophysectomy in Ciba Foundation Colloquia on Endocrinology. Boston, Little, Brown and Company, 1955, vol. 8, p. 438.

\section{SPECIAL NOTICE TO SUBSCRIBERS}

Post Offices will no longer forward the Journal when you move. Please notify The Journal of Clinical Investigation, Business Office, 333 Cedar Street, New Haven 11, Conn., at once when you have a change of address, and do not omit the zone number if there is one. 